Якимчук T. I. [1; ORCID ID: 0000-0003-2983-1329], ст. викладач

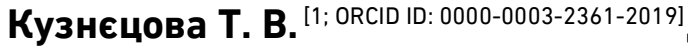
к.е.н., професор,

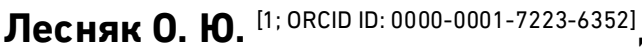
к.е.н., доцент,

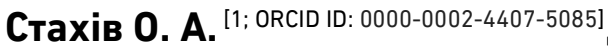
к.е.н., доцент

${ }^{1}$ Національний університет водного господарства та природокористування, м. Рівне

\title{
УПРАВЛІННЯ ЕКОНОМІЧНИМИ РИЗИКАМИ У МІЖНАРОДНОМУ МАРКЕТИНГУ
}

У цій роботі представлена модель оцінки ризиків та моделі управління економічною безпекою для компонентів та підсистем міжнародного маркетингу. Розробка моделі базується на принципах та інструментах класичної теорії управління ризиками, пристосованої до особливостей міжнародного маркетингу. На основі ґрунтовного огляду літератури було сформовано вичерпний перелік факторів ризику. Використано структуру аналізу ризиків та розроблено модель для кількісної оцінки факторів ризику. Модель також може бути використана для оцінки та вибору критеріальних підходів в міжнародній маркетинговій діяльності.

Ключові слова: міжнародний маркетинг; управління ризиками; економічний ризик; економічна безпека; міжнародні ринки.

Постановка проблеми. Ризик - це один з базових аспектів міжнародного бізнесу. Через ускладнення ведення господарської діяльності в умовах глобалізації зростає кількість та різноманітність ризиків. Для досягнення успішної ринкової діяльності, в тому числі і міжнародного бізнесу, необхідна здатність ретельно оцінювати пов'язані з нею ризики, намагатися управляти ними, та, якщо це можливо, уникати їх, водночас підтримуючи прибутковість діяльності.

В міжнародній маркетинговій діяльності розвинені країни вважаються менш ризикованими ніж країни, що розвиваються. Тому в умовах України рівень ризику може вважатися високим, що ще більш актуалізує важливість розробки підходів до його управління. У зв'язку з цим можна відзначити, що конкуренція є найгострішою на ринках, які вважаються безпечними, і низька на так званих 
небезпечних ринках. Передбачити, які сектори та національні економіки можуть бути ризикованими та навчитися керувати рівнем такого ризику і є завданням економічних досліджень.

Аналіз останніх досліджень та публікацій. Питання економічної безпеки та економічного ризику висвітлені в українських та закордонних публікаціях досить деталізовано. Фундаментальні основи теорії управління економічним ризиком та економічною безпекою у ринковій економіці висвітлені в працях таких відомих дослідників як Вітлінський В. В., Вяткін В. Н., Х Хохлов Н. В. Старостіна А. О., Кравченко В. А, Мараховська Т.А. та ін. Ризики як одна 3 базових економічних категорій розглянуті в працях закордонних науковців Котлер Ф., Альт Шулер І., Клементс С., Доннеллан М. та багатьох інших.

Проте незважаючи на значні досягнення в сфері досліджень економічного ризику, розгляд питань та характеристик ризику міжнародного маркетингу $\epsilon$ недостатнім. Потребують більш деталізованого вивчення питання розробок бізнес-стратегій, що базуються на принципах економічної безпеки, а також вивчення економічних ризиків міжнародних маркетингових досліджень.

Постановка завдання. Метою статті $€$ визначення особливостей впливу рівня економічного ризику на міжнародну маркетингову діяльність. Для досягнення поставленої мети аналізуються теоретичні та практичні аспекти управління підприємницькими ризиками та міжнародні маркетингові дослідження, ризикоорієнтовані управлінські практики. Одним із завдань дослідження $€$ розгляд відокремленого та синергетичного впливу управлінських практик на підтримання економічної безпеки та управління ризиками міжнародного маркетингу.

Основним завданням є оцінка впливу економічних ризиків на заходи та підходи міжнародного маркетингу, яка б показала, внаслідок зміни котрих з чинників міжнародна маркетингова діяльність була б в змозі відповідати принципам економічної безпеки.

Виклад основного матеріалу. У міжнародному маркетингу питання прийняття ризиків зазвичай є одним з основних аспектів підприємницької діяльності. На початкових етапах інвестування обирається політика уникнення ризиків, проте поступово з'являється необхідність стикатися з все більшою кількістю та масштабністю загроз.

Різні типи ризиків, з якими може зіткнутися міжнародний маркетолог, можна розділити на такі категорії [1]:

- комерційні ризики; 
- політичні ризики;

- транспортний ризик;

- кредитний ризик;

- ризик валютних коливань;

- валютний ризик.

До комерційних ризиків можна віднести ризики, що виникають внаслідок непридатності продукту для певного ринку чи невідповідності товару стандартам, прийнятим в певній галузі чи національній економіці. При цьому така невідповідність може бути як товарного, так і фінансового характеру. Можна загалом сказати, що експортна торгівля є більш ризикованою, ніж внутрішня торгівля.

Комерційний ризик відноситься до потенційної втрати або невдачі фірми внаслідок погано розроблених або виконаних бізнесстратегій, тактик або процедур. Менеджери можуть робити неправильний вибір у таких сферах, як вибір ділових партнерів, терміни виходу на ринок, ціноутворення, створення характеристик товару та рекламних стратегій. Хоча такі невдачі існують і у вітчизняному бізнесі, наслідки, як правило, дорожчі, коли вони трапляються за кордоном. Наприклад, у вітчизняному бізнесі компанія може припинити роботу погано діючого дистриб'ютора просто заздалегідь повідомивши про це. Однак на зовнішньому ринку припинення ділового партнерства може виявитися дорогим через протекціоністські правила, що захищають місцеві фірми. Маркетинг неповноцінних або шкідливих продуктів, що не відповідають очікуванням споживачів, ненадання належного обслуговування споживачів та ін. може зашкодити репутації фірми та її міжнародним показникам.

Для більшості комерційних ризиків немає можливості перекласти ризик на професійних носіїв ризику, і фірми-експортери повинні приймати такі ризики самостійно. Однак ці ризики можна зменшити, застосовуючи методи прогнозування, а також стежачи за зміною умов ведення бізнесу у відповідних країнах, а також міжнародної економіки в цілому. Потрібно бути готовим до будь-яких несприятливих змін та вжити коригувальних заходів якомога швидше, коли ситуація цього вимагає.

Під національним ризиком (також відомим як політичний ризик) розуміються потенційно несприятливі наслідки для діяльності компанії та прибутковості, спричинені розвитком політичного, правового та економічного середовища в іноземній країні. Ризик країни включає можливість втручання іноземних держав у 
господарську діяльність фірм. Наприклад, уряди можуть обмежити доступ до ринків, накласти бюрократичні процедури на ділові операції та обмежити обсяг заробленого доходу, який фірми можуть приносити додому від іноземних операцій. Ступінь державного втручання у комерційну діяльність у різних країнах різниться. Наприклад, Сінгапур та Ірландія характеризуються значною економічною свободою, тобто досить ліберальним економічним середовищем [2]. На відміну від цього, китайський та російський уряди регулярно втручаються у ділові справи. Ризик країни також включає закони та нормативні акти, які потенційно можуть заважати діяльності та діяльності компанії. До критичних правових аспектів належать права власності, захист інтелектуальної власності, відповідальність за продукцію та податкова політика. Національні економіки приховують неявні, але потенційно шкідливі економічні умови, наприклад через високу інфляцію, державний борг та незбалансовану міжнародну торгівлю.

Комерційне законодавство в різних країнах може значно відрізнятися. При необхідності юридичного супроводу слід прийняти до уваги, що ведення судового провадження в іноземній країні $\epsilon$ складнішим та менш передбачуваним. Основні ризики можна усунути, визначивши договірним шляхом, яке законодавство застосовуватиметься, і в якому суді розглядатимуться можливі юридичні суперечки. Але навіть в таких обставинах підвищені ризики міжнародного маркетингу залишаються і повинні оцінюватися як частина загального планування міжнародної маркетингової експансії [3].

Зміни обмінних курсів валют країни або іноземних валют також можуть серйозно вплинути на очікувані результати міжнародної господарської діяльності. Валютний ризик (також званий фінансовим ризиком) полягає в ризику несприятливих коливань курсів валют. Коливання є зазвичай мало прогнозованими проте можуть значно впливати на прогнозовані результати господарювання внаслідок не лише фінансових але і податкових впливів. Валютний ризик виникає через те, що міжнародні операції часто проводяться в декількох національних валютах. Коли вартість валюти істотно коливається, вартість активів, доходів та операційних доходів фірми може бути коригована. Витрати на імпорт деталей або деталей, що використовуються у виробництві готової продукції, можуть різко зрости, якщо вартість валюти, в якій деномінований імпорт, різко зросте. Інфляція та інші шкідливі економічні умови, що 
спостерігаються в одній країні, можуть мати негайні наслідки для обмінних курсів через зростаючу взаємозв'язок національних економік, причому амплітуда таких коливань, при інших сприятливих умовах, може бути критичною для підтримування ефективності господарювання.

Нами було розроблено таку модель управління ризиками міжнародного маркетингу.

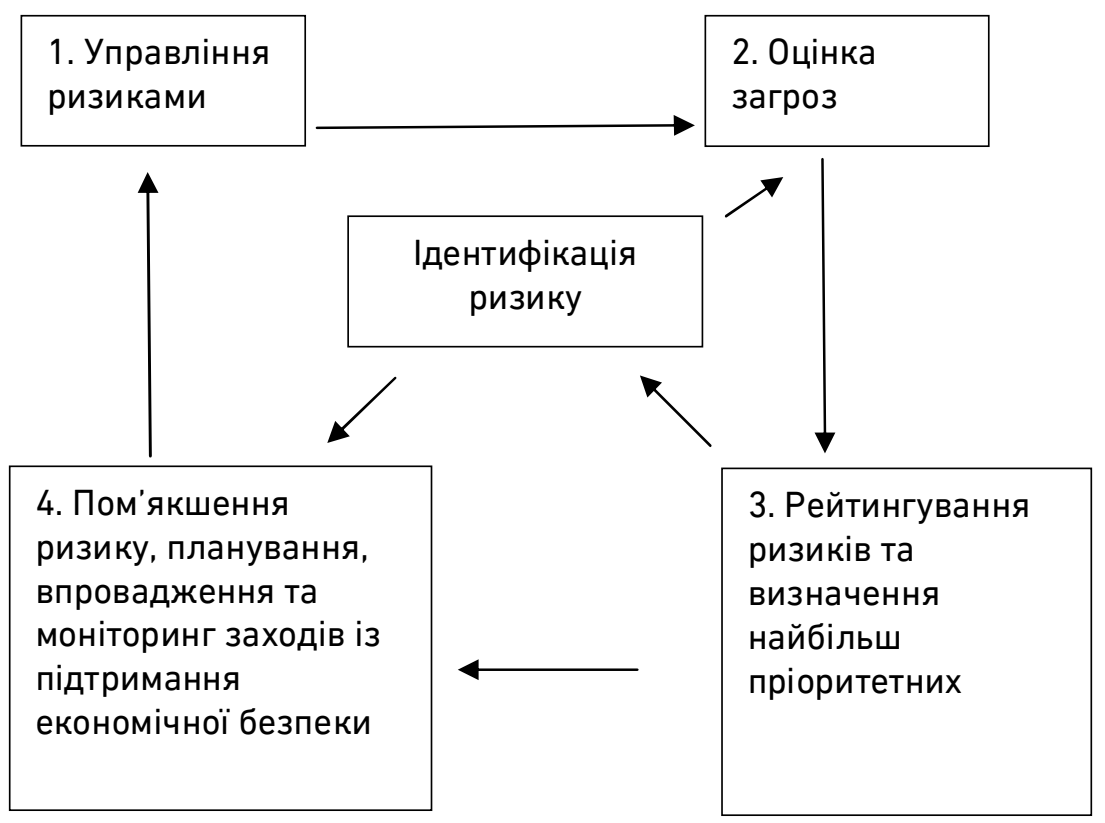

Рисунок. Модель управління економічними ризиками міжнародного маркетингу

Управління ризиками має бути пріоритетом на всіх рівнях управління. Ідентифікація ризику буде неповною без ґрунтовного аналізу економічного середовища. Обмін інформацією про ризики важливий для підтримання синергетичного ефекту при забезпеченні прийняття ефективних управлінських рішень у міжнародному маркетингу

Висновки. Національні відмінності вимагають від менеджерів формулювання підходів, пристосованих до умов у кожній країні, де фірма веде бізнес. Відмінності, як правило, вимагають від фірм істотних змін у своїх продуктах та послугах.

Дослідження окремих і синергетичних підходів до управління бізнес-ризиками в міжнародному маркетингу дозволяє зробити наступні висновки. Необхідно використовувати методи управління 
бізнес-маркетинговими ризиками. Використання таких методик дозволяє бізнесу реалізувати свої конкурентні переваги. Скоординоване застосування управління бізнес-ризиками призводить до синергетичного ефекту в забезпеченні міжнародної конкурентоспроможності підприємств і національної економіки. Використання синергетичного підходу $€$ об'єктивно зумовленим процесом, який залежить від ряду факторів міжнародної бізнессередовища, оцінка і прогнозування яких є важливим завданням при прийнятті маркетингових рішень.

1. Вітлінський В. В., Великоіваненко Г. І. Ризикологія в економіці та підприємництві : монографія. К. : КНЕУ, 2004. 480 с. 2. Котлер Ф. Основы маркетинга: краткий курс / пер. с англ. Москва : ИД Вильямс, 2012. 496 с. 3.Голяш І., ДанилюкІ. Аналіз маркетингових ризиків підприємства. Економічний аналіз : зб. наук. праць каф. екон. аналізу і статистики Терноп. нац. екон. ун-ту. Тернопіль, 2012. Вип. 10. Ч. 4. C. 59-62.

\section{REFERENCES:}

1. Vitlinskyi V. V., Velykoivanenko H. I. Ryzykolohiia v ekonomitsi ta pidpryiemnytstvi : monohrafiia. K. : KNEU, 2004. 480 s. 2. Kotler F. Osnovyi marketinga: kratkiy kurs / per. s angl. Moskva : ID Vilyams, 2012. 496 s. 3. Holiash I., Danyliuk I. Analiz marketynhovykh ryzykiv pidpryiemstva. Ekonomichnyi analiz : zb. nauk. prats kaf. ekon. analizu i statystyky Ternop. nats. ekon. un-tu. Ternopil, 2012. Vyp. 10. Ch. 4. S. 59-62.

Yakymchuk T. I. [1; ORCID ID: 0000-0003-2983-1329],

Senior Lecturer,

Kuznietsova T. V. [1; ORCID ID: 0000-0003-2361-2019] Candidate of Economics (Ph.D.), Professor,

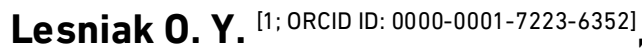
Candidate of Economics (Ph.D.), Associate Professor,

Stakhiv 0. A. ${ }^{[1 ; 0 R C I D ~ I D: 0000-0002-4407-5085], ~}$ Candidate of Economics (Ph.D.), Associate Professor

${ }^{1}$ National University of Water and Environmental Engineering, Rivne

\section{ECONOMIC RISK MANAGEMENT IN INTERNATIONAL MARKETING}

This paper presents a risk assessment model and economic security management model for components and subsystems of international marketing. The development of the model is based on the principles and 
tools of the classical theory of risk management, adapted to the peculiarities of international marketing. Based on the review of the literature, an exhaustive list of risk factors was formed.

The purpose of the article is to determine the impact of the level of economic risk on international marketing activities. To achieve this goal, theoretical and practical aspects of business risk management and international marketing research, risk-oriented management practices are analyzed. One of the objectives of the study is to consider the separate and synergistic impact of management practices on maintaining economic security and risk management in international marketing.

The main task is to assess the impact of economic risks on the measures and approaches of international marketing, as a result of changes in which of the factors of international marketing activities would be able to meet the principles of economic security.

The structure of risk analysis is used and a model for quantitative assessment of risk factors is developed. The model can also be used to evaluate and select criteria in international marketing decisions.

National differences require managers to formulate approaches due to the conditions in each country. Differences typically require firms to make significant changes to their products and services.

It is necessary to use methods of business marketing risk management to improve competitive advantages. Coordinated application of business risk management leads to a synergistic effect in ensuring the international competitiveness of enterprises and the national economy. The use of a synergetic approach is an objectively determined process that depends on a number of factors of the international business environment, the evaluation and forecasting of which is an important task in marketing decisions making.

Keywords: international marketing; risk management; economic risk; economic security; international markets. 
Якимчук Т. И. ${ }^{[1 ; 0 R C I D ~ I D: 0000-0003-2983-1329], ~}$

ст. преподаватель,

Кузнецова Т. В. [1; ORCID ID: 0000-0003-2361-2019],

к.э.Н., профессор,

Лесняк О. Ю. [1; ORCID ID: 0000-0001-7223-6352]

к.э.Н., доцент

Стахив О. А. ${ }^{[1 ; 0 R C I D ~ I D: 0000-0002-5786-3267] ~}$

к.э.н., доцент

${ }^{1}$ Национальный университет водного хозяйства и природопользования, г. Ровно

\section{УПРАВЛЕНИЕ ЭКОНОМИЧЕСКИМИ РИСКАМИ В МЕЖДУНАРОДНОМ МАРКЕТИНГЕ}

В этой работе представлена модель оценки рисков и модели управления экономической безопасностью для компонентов и подсистем маркетинга. Разработка модели базируется на принципах и инструментах классической теории управления рисками, приспособленной к особенностям маркетинга. На основе обстоятельного обзора литературы был сформирован исчерпывающий перечень факторов риска. Использована структура анализа рисков и разработана модель для количественной оценки факторов риска. Модель также может быть использована для оценки и выбора критериальных подходов в международной маркетинговой деятельности.

Ключевые слова: международный маркетинг; управление рисками; экономический риск; экономическая безопасность; международные рынки. 